\title{
An Insight into Rodrik's Paradox of Globalization
}

Dr. Puja Saxena Nigam ${ }^{*}$
$\begin{gathered}\text { Article History } \\ \text { Received: } 03.02 .2021 \\ \text { Accepted: } 05.04 .2021 \\ \text { Published: } 10.04 .2021\end{gathered}$
Journal homepage:
https://www.easpublisher.com
Quick Response Code

\begin{abstract}
Copyright (C) 2021 The Author(s): This is an open-access article distributed under the terms of the Creative Commons Attribution 4.0 International License (CC BY-NC 4.0) which permits unrestricted use, distribution, and reproduction in any medium for non-commercial use provided the original author and source are credited.
\end{abstract}

\section{EVOLUTION OF GLOBALIZATION}

The signs of modern globalization can be traced back to the Silk Route trade (1st Century BC-5th Century AD and 13th-14th Century AD) but the first wave of globalization occurred post the Industrial Revolution till the advent of World War I. The outbreak of World War I brought an end to just about everything the burgeoning high society of the West was used to, including globalization. It was ultimately the end of World War II that marked a new beginning for the global economy and with that came the second and third wave of Globalization that lasted till the end of 20th Century. This phase of Globalization was characterized by the technological development and Capital movement among nations as more and more economies moved towards an open regime. The fourth wave of Globalization, the one that began at the end of the 20th Century is where the developed and developing countries became more equal partners in the flow of cross border Trade and Investment, as per capita incomes between the developed world and developing world started converging energized by the awakening of sleeping giants, China and India.

Hyper-globalization is the dramatic change in the size, scope and velocity of Globalization that began in the late 1990's and continues into the 21 st Century. It includes economic, cultural and political Globalization.
Takashi Inoue extended the concept to beyond economics into the realms of culture and politics. He argues that the world is being transformed by three forces of hyper-globalization: economic (in which extensive growth in global trade creates cross-border economic integration), social media (human communication force via the Internet that are changing norms blurring social barriers) and new disruptive technologies that are accelerating the pace of change in all spheres (Internet-Of-Thing, Big Data and Artificial Intelligence).

Dani Rodrik has criticized the state of Globalization, questioning the wisdom of unlimited economic integration beyond National borders. The deep integration of Hyper-globalization conflicts and threatens the Sovereignty of the nation state. He concludes that Hyper-globalization is Globalization that has gone too far.

\section{THE PROS AND CONS}

Globalization has been an extremely controversial issue and many economic, political and social thinkers have argued about it. While it is evident that trade and economic growth have been on a rapid rise in the wake of globalization, it is not difficult to argue how globalization has undermined the nation states, eroded the state sovereignty, limited the 
flexibility within governments, has affected the wage earners adversely across the developing world so much so that the free trade that was initially intended to cover wage gaps has ended up increasing them substantially. So while the process of cultural homogenization has led to a positive dissemination of feminist ideals across the globe and an increasing recognition of women's rights that is global feminism, it on the other hand has led to feminization of globalization that explains the kind of jobs women are a part of and the low wages of such industrial enclave where women in majority are employed. The discontent from Globalization stems from the fact that poverty and instability goes hand in hand with growth and trade.

As increased Globalization brings in multifaceted benefits, it ensures the problems don't get bound by national borders as is the present pandemic that engulfed the entire world in no time facilitated by easy movement across the world.

\section{THE BOOK}

Rodrik has provided a historical assessment of the interaction between states and markets. The "globalization's conundrum "as he calls it is explained as the problem of global markets that are doubly problematic: they lack the institutional underpinnings of national markets and they fall between existing institutional boundaries. He discusses first the ascendancy of free trade beliefs during the nineteenth century thanks to the efforts of economists such as David Ricardo and John Stuart Mill, and then considers the gold standard and its eventual demise, with a brief exposé of the calamitous protectionism in the interwar period. He then makes a qualified case for free trade in the context of its implications for distributive justice and social norms. He discusses the Bretton Woods regime ("compromise") and institutional framework and the move from the transitional General Agreement on Tariffs and Trade (GATT) (following the failed International Trade Organization) to the permanent World Trade Organization (WTO). Drawing on Robert Lawrence, Rodrik makes a distinction between "shallow" and "deep" integration:

Under shallow integration, as in Bretton Woods, the trade regime requires relatively little of domestic policy. Under deep integration, by contrast, the distinction between domestic policy and trade policy disappears. Global rules in effect become the domestic rules.

He concludes that the reality is that we lack the domestic and global strategies to manage globalization's disruptions. As a result, we run the risk that the social costs will outweigh the narrow economic gains and spark an even worse globalization backlash. He also discusses what he calls "Financial Globalization Follies," commencing with the demise of the Bretton Woods consensus on capital controls and fixed exchange rates, and concludes that "financial globalization has failed us" and that countries that have opened themselves to international capital markets have faced great risks and crises. He divides economists into two groups, foxes and hedgehogs. Rodrik draws on the ancient saying attributed to the Greek poet Archilochus that "the fox knows many things, but the hedgehog knows one big thing" and compares "the hedgehogs who think freeing up markets is always the right solution (the 'big idea') and the foxes who believe the devil is in the details". He considers himself amongst the "foxes, "and recommends skepticism towards the hedgehog type of economists who sport one big idea (be it "efficient market hypothesis" or "rational expectations"). He is rightly concerned about "the huge chasm that has developed between the reach of financial markets and the scope of their governance" but firmly rejects the case for global financial regulation: "The very idea that we could erect a perfect system of global regulation for international financial flows is itself a fairy tale" Rodrik considers different country experiences, contrasting the resulting poverty in many countries in Africa with the success stories of east Asia, in particular China. Rodrik states that politics is only part of the answer, and goes on to explain the economic narrative to understand these divergences. He criticizes "trade fundamentalists" and advocates a new development strategy (a "post-Washington consensus" consensus) recalibrating the balance between states and markets.

Rodrik argues that we cannot have "deep economic integration" (he uses the term "hyperglobalization"), national sovereignty (nation state), and democratic politics all at once. There can be at most two out of three. Since democracy cannot be compromised, and he rejects the "global governance" option, he proposes a return to national sovereignty. He considers that: global standards and regulations are not just impractical; they are undesirable. The democratic legitimacy constraint ensures that global governance will result in the lowest common denominator, a regime of weak and ineffectual rules. His solution to strengthen the nation state is a critique of hyper-globalization. He considers that this hyper-globalization agenda gives predominance to the needs of multinational enterprises, big banks and investment houses over other social and economic objectives and further elaborates his case against "global governanc" [1-3].

\section{THE PARADOX}

Dani Rodrik has been a vocal critic for over a decade of what he sees as the unbridled tide of globalization present in the worldwide economy. He has put forth the "The Globalization Paradox" where he sets out the perils of financial globalization without any constraints as is perfectly evidenced by the most recent financial crisis and the rapid domino effect on the world. He cautions how the crisis was predictable and that economists became blind to the pitfalls as they 
believed too strongly on how markets are efficient, financial innovation transfers risk to the best able to bear it, self-regulation works best and Government intervention is ineffective and harmful.

He believes in the power of globalization to lift the world out of poverty but that needs to be done more thoughtfully. In order to bring out the proper economic benefits of globalization that are broadly distributed throughout society, national democracies need to be strengthened and International Rules need to be in place, that protect all players while allowing for maneuverability and enterprise. This stands in sharp contrast to the doctrine of complete flow of capital with minimal regulation.

Rodrik sets out his paradox in the form of a "trilemma" where Democracy, National determination and Economic globalization cannot be simultaneously pursued. One of these has to be foregone in a spirit to pursue the other two.

A simple depiction of the trilemma can be:

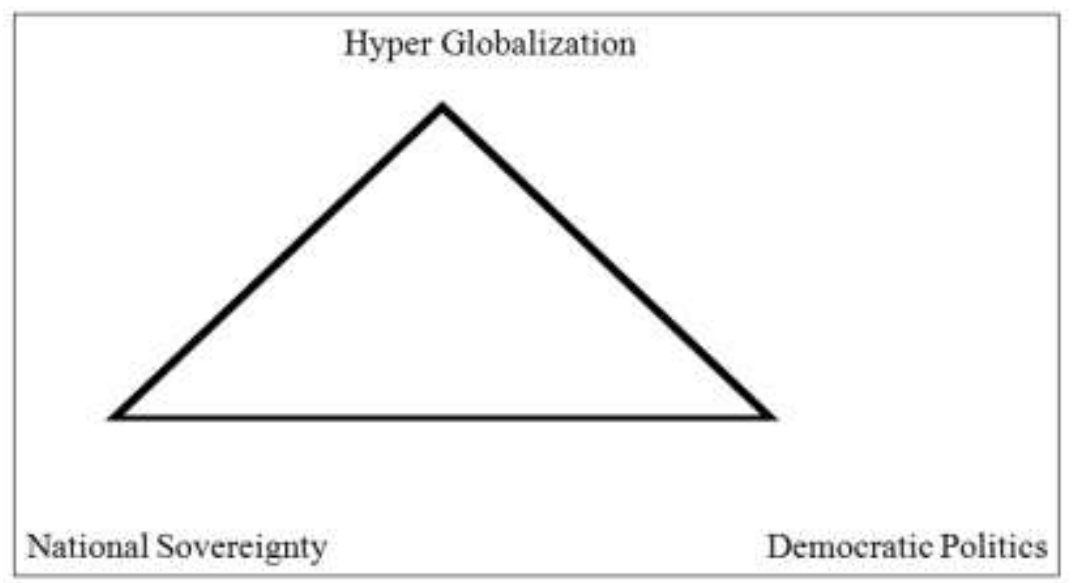

While a golden straitjacket (a term coined by Thomas Friedman that describes the political constraints that countries face when they subscribe to the free markets) can best describe one side of this trilemma wherein Hyper globalization goes hand in hand with National Sovereignty, Bretton woods compromise suits the combination of National Sovereignty and Democratic politics and Global Governance is where Hyper Globalization can be achieved with Democratic politics.

Rodrik talks about the collapse of the Gold Standard era, the post-war Bretton woods Regime, Washington Consensus and the political discourses that shaped their aftermath and the role of institutions like the IMF, the WTO and the World Bank. Countries like India and China he believes have prospered by not being dependent on International Finance in the era of Globalization, but rather by being selective in deals that they took up; lent money to rich countries than they borrowed; pursued mixed strategies with strong State intervention and regulation with clearly defined goals for their own societies. He refers to Latin American countries who have not had such policies and have fallen victim to the downsides of globalization.

Rodrik states the seven principles for a new model of globalization, after considering how intertwined the concepts of globalization and capitalism have become. The first principle, contends that markets need other institutions to support them, notably courts of justice, legal arrangements to enforce property rights, and regulations to rein in abuse and fix market failures, since "markets do not create, regulate, stabilize or sustain themselves." Interestingly, he points out that "what is true of domestic markets is true also of global ones." The logical extension of his argument (which would contradict a basic tenet of the book, Rodrik's choice to solve the "trilemma") is that if national markets need adequate national rules, international markets need adequate international rules! This would mean that national sovereignty, rather than global governance, should be sacrificed in order to solve the "trilemma". The other six principles deal with a number of issues including democracy and legitimacy in the context of nation states, different ways of achieving prosperity and the role of non-democratic countries. Not all the principles are equally relevant and there are some inter-linkages.

Need of the hour Rodrik writes that a delicate balance exists between Democracy and processes of Globalization. He expresses his argument in the form of a syllogism:

Markets require a wide range of non-market institutions (of regulation, stabilization and legitimation) in order to work well and remain socially sustainable. These institutions do not take unique forms, such that ultimate goals of efficiency or stability can be achieved under a variety of designs and blueprints. The needs and preferences of different set ups/frameworks are different so market-supporting institutions take different shapes and perform different functions. A 
world that is sufficiently responsive to democratic preferences will therefore, be one with institutional diversity and heterogeneity rather than institutional harmonization and convergence. Since, institutional diversity inhibits the global integration of markets, a world that is sufficiently responsive to democratic preferences will also be the one that is short of full globalization.

After the Global Financial Crisis, it is apparent that there is a need for adequate regulation of World Financial markets especially in the absence of information (asymmetries), systemic risk etc. However, a single global regime of financial regulation is not desirable and feasible due to different needs and uses in the entire world that comprises different countries and regions. Hence, the need for a global financial system does not translate into one.

International Trade that is free trade may not always go in solidarity with domestic framework and may place countries on different points in the global efficiency frontier. While the need is for markets to have institutions of collective deliberation and social choice, democracy emerges as the only set up that can support this. He rejects the role of intergovernmental organizations as a way to provide governance as it is incompatible with democracy. He does not argue to stop or reduce globalization but to change the rules of the game away from hyper-globalization to a form that does not conflict with sovereignty.

To sum up, the trade-off and the risk of the economic gains of globalization being outweighed by its social costs primarily the nation states losing their autonomy in essence is what Rodrik calls the Globalization paradox. Unfettered globalization has created fear and insecurity because of its uneven effects on income distribution, the deterioration of the environment and pressure of the liberal welfare state. It threatens the cohesiveness of societies, fuels distrust into the political process and leads to xenophobic and protectionist tendencies exploited by populist politicians. It has reduced the regulatory power of nation states to a minimum without this gap being filled by a global governance system. If left to itself, globalization will lead to a winner-takes-all situation where large and big enterprises reap all benefits at the expense of social cohesion, welfare of all and the Environment. A society based economic system driven by peculiarities of individual economies reaffirming the interests of all sections of people and a role of International organizations retaining the interests of all countries of the world can be the best way forwarded. The implementation though may require a fierce power struggle at all levels!!!!

\section{REFERENCES}

1. Public Relations in Hyper-globalization: Essential Relationship Management - A Japan Perspective, Takashi Inoue, Routledge, 2018

2. Rodrik, D. (2011). The Globalization Paradox. Norton \& Company, Inc. ISBN 978-0-393-07161$\underline{0}$.

3. Rodrik, D. (1997). Has Globalization Gone Too Far?. Institute for International Economics. ISBN $\underline{978-0-88132-241-5}$

Cite This Article: Puja Saxena Nigam (2021). An Insight into Rodrik's Paradox of Globalization. East African Scholars J Econ Bus Manag, 4(3), 51-54. 